\title{
SELECTION OF THE BEST PREWEDDING PHOTO LOCATION USING THE AHP METHOD
}

\author{
Muhammad Noval Alfarizi ${ }^{1}$, Mariah Nur Azizah², Wikara Dwi Saputra ${ }^{3,}$ Siti Ernawati ${ }^{*}$ ) \\ Program Studi Sistem Informasi \\ Universitas Nusa Mandiri \\ muhammadnoval616258@gmail.com¹, mariahazizah@gmail.com², wikaradwi.saputra14@gmail.com³, \\ siti.ste@nusamandiri.ac.id ${ }^{4}$ \\ (*) Corresponding Author
}

\begin{abstract}
Abstrak
Lokasi foto prewedding merupakan sebuah tempat yang dapat menggambarkan kebahagiaan calon pengantin. Dalam kondisi tersebut terkadang masyarakat umum khususnya calon pengantin dan fotografer mengalami kesulitan dalam memilih lokasi foto prewedding terbaik. Maka mengakibatkan pengambil keputusan akan mendapatkan lokasi foto prewedding yang tidak sesuai dengan apa yang diharapkan. Dalam penelitian ini memanfaatkan Metode Analytical Hierarchy Process (AHP) untuk membantu calon pengantin maupun fotografer dalam memilih lokasi foto prewedding terbaik khususnya di daerah Jakarta. Penelitian ini menggunakan enam kriteria diantaranya jarak lokasi, jumlah spot, transportasi, waktu, biaya lokasi, dan tema. Dari Hasil analisa dan pengolahan data diperoleh bahwa Ancol unggul dengan nilai 0,224047721 (22\%) berbandingan dengan cafe batavia dengan nilai 0,195494507 (20\%), pelabuhan sunda kelapa dengan nilai 0,187335550 (19\%), taman wisata mangrove angke kapuk dengan nilai 0,171584976 (17\%), kota tua dengan nilai 0,162696386 (16\%), dan glodok dengan nilai 0,058840858 (6\%).
\end{abstract}

Kata kunci: lokasi foto prewedding, analytical hierarchy process, sistem penunjang keputusan

\begin{abstract}
The location of the photo prewedding is a place that can describe the happiness of the bride and groom. In these conditions sometimes the general public especially prospective bride and groom and the photographer have difficulty in choosing the location of the photo prewedding best. Then the resulting decision-makers will get the location of the photo prewedding which is not in accordance with what is expected. In this study utilizes the Method of Analytical Hierarchy Process (AHP) to help the bride and groom and the photographer in choosing the location of the photo prewedding best, especially in the area of Jakarta. This study using six criteria such as distance, number of spots, transportation, time, cost, location, and theme. From the Results of the analysis and processing of the data obtained that the Ancol with superior value $0,224047721(22 \%)$ berbandingan to cafe batavia with a value of $0,195494507(20 \%)$, sunda kelapa harbor to the value $0,187335550(19 \%)$, taman wisata mangrove angke kapuk with a value of 0,171584976 $(17 \%)$, old city, with the value of $0,162696386(16 \%)$, and glodok, with a value of $0,058840858(6 \%)$.
\end{abstract}

Keywords: pre-wedding photo locations, analytical hierarchy process, decision support system

\section{INTRODUCTION}

The location of the photo prewedding is a place that can describe the happiness of both pairs of the bride and groom. In reality, photo prewedding like this just as a complement to a wedding procession, but for most people a photo prewedding is very important. No Wonder if many people are willing to pay money to hundreds of millions for a photo prewedding (Kusuma, 2010). The problem is either that the general public especially prospective bride and groom and the photographer have difficult in choosing the location of the photo prewedding best in jakarta. As a result, decision- makers will get the location of the photo prewedding which is not in accordance with what is expected. The bride and groom or the photographer should have some options or special consideration in choosing the location of the photo prewedding best. Consideration or the option can be any number of spot, a distance of location, transportation, fees and other (Syahputra, Winanjaya, \& Okprana, 2019). When talking about a location or a place of interest to be used as the location of the photo prewedding, general public or a bride looking for information through friends, friends, family, and the internet. Such information can also they get better it's through social media, or search sites like Google. 
Information from various sources will they compare to get the right location. Even so, the amount of information obtained to make the general public especially prospective bride and groom and the photographer difficulties in screening. This makes the general public who will do a photo prewedding feel hesitate in determining the location. The presence of such doubt strengthen the desire of researchers to create a decision support system the selection of the location of the photo prewedding.

Decision support system is a system specific information that is used to help management to take decisions related to semistructured problems. This system has the usefulness to get some alternatives that are interactive can be used by the user (Latif, Jamil, \& Abbas, 2018). Decision support system is one of the computer-based system including systems of knowledge-based or knowledge management that can be used to support decision-making in a company or organization (Safitri \& Tinus Waruwu, 2017). DSS can create quick decision-making, either in a group or individual to be able to determine an objective decisions. The reason DSS very necessary, because of the amount of information and data that allows to use DSS (Utama, 2017).

There are some studies related to the use of the method of Analytical Hierarchy Process to get the best options, including :

The research discussed about the selection of subjects the practice of using AHP method which has 6 criteria and 6 alternative. From to 6 alternate owned, an alternative to A4 has a priority value and the percentage of the highest priority that is 0,235 and 23,5. Based on these results demonstrate that the alternative to A4 be selected according to the criteria of the existing (Azhar, 2019).

Research regarding the selection of laptops for the needs of the operational Directorate of Course and Training KEMDIKBUD by using the AHP method, which has 5 criteria and 3 alternatives. From the $3^{\text {rd }}$ alternative, an alternative to a-1 (Laptop A) to have the highest value, i.e. to 39,9\%. Based on these results, a Laptop A is superior to other alternatives in the selection of the laptop to operational needs (Sanyoto, Handayani, \& Widanengsih, 2017).

Based on the research related to the above, the obtained gap analysis or the analysis of the problem which the researcher has made the following:

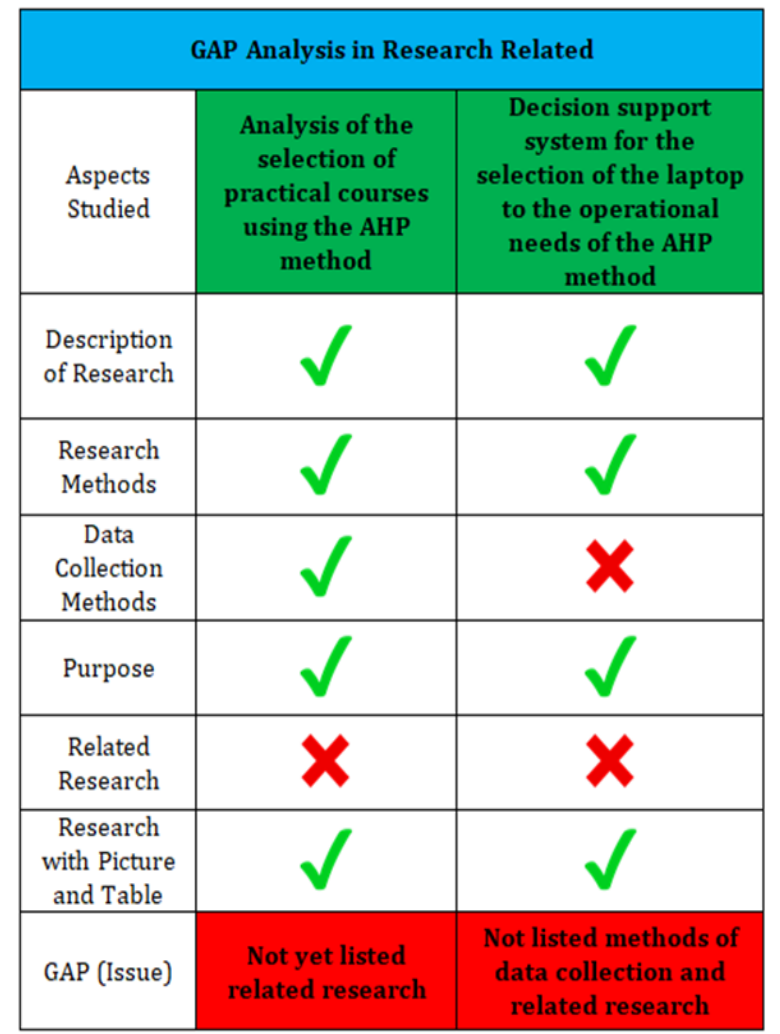

Figure 1. Gap Analysis

From Fig.1. Gap Analysis above, there are several problems that exist in the 2-related research. to it it can be a material consideration to be able to include in this study.

In this research, the researcher uses the method of Analytical Hierarchy Process (AHP) which is a method to be able to decipher a problem with many complex criteria into a hierarchy (Nurhidayah, Fauzan, \& Rahayu, 2020). AHP is a theory of measurement that can be used to find the scale ratio with how to perform a pairwise comparison between elements (Muhaimin Hasanudin, Yansen Marli, 2018). The advantages of the use of AHP is that it can easily determine the choice of location prewedding by using the calculation centralized on the weights of the criteria, respectively. Another reason researchers use the method of Analytical Hierarchy Process (AHP) because basically AHP included in the methods section with the primary inputs are the human perception (Sanyoto et al., 2017).

The purpose of this research is to facilitate the general public especially prospective bride and groom and the photographer to select the location of photo prewedding best in jakarta. 


\section{RESEARCH METHODS}

The quantitative approach used in this research, where data collection was done using questionnaires. This research using the method of AHP (Analytical Hierarchy Process) consider the six criteria, namely the distance of the location, the number of spot, transportation, time, cost, location, and theme. Figure 2 shows the stages of the research conducted.

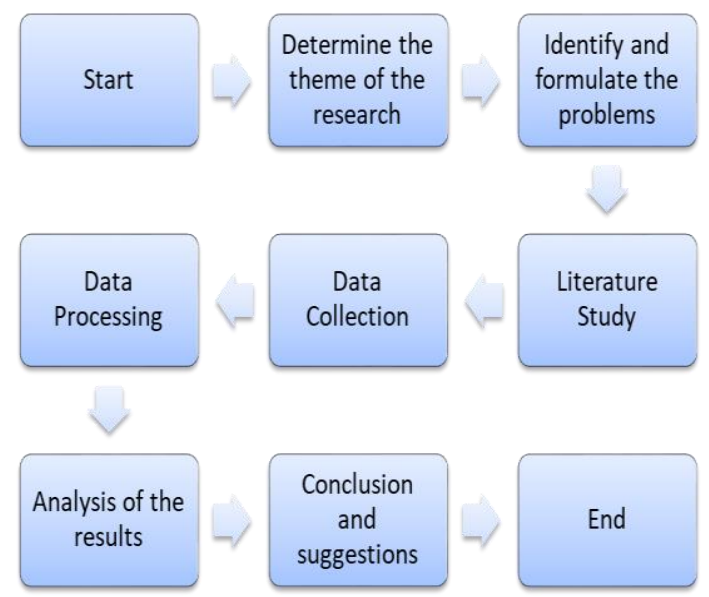

Figure 2. Stages of Research

\section{Population and Study Sample}

After the questionnaire was distributed to the community at large, obtained the 53 respondents who have answered the question or questionnaire that has been given. Table 1 is the data of the respondents that displays the position of the 53 respondents have been obtained.

Table 1. The Data of Respondents

\begin{tabular}{clc}
\hline No. & \multicolumn{1}{c}{ Position } & amount \\
\hline 1 & School students & 1 \\
2 & Teachers & 1 \\
3 & Photographer & 1 \\
4 & Marketing & 1 \\
5 & Entrepreneurs & 1 \\
6 & Telemarketing & 1 \\
7 & Administration & 1 \\
8 & Graphica & 1 \\
9 & Wood Artisans & 1 \\
10 & Housewife & 2 \\
11 & Entrepreneurs & 2 \\
12 & Employees & 3 \\
13 & Female employees & 3 \\
14 & Private employees & 6 \\
15 & College students
\end{tabular}

Data Analysis Techniques

Analysis is a critical stage in the methodology of scientific research, for the reason when doing the analysis of such data can give the sense and meaning which is very useful in resolving the problem. The stage of data Analysis has the aim to provide a clear understanding of the working of DSS, so that the strengths and weaknessess of DSS can be seen with the implementation of the method of Analytical Hierarchy Process (AHP). The method of Analytical Hierarchy Process is a method to be able to take a comprehensive decision (Frieyadie, 2018), to apply the AHP method with the wellneeded goal (goal), the criteria and the alternatives. Then the calculation can be done to get the best alternative (Syahputra et al., 2019).

To determine the location of photo prewedding best in jakarta with the use of AHP, it takes the criteria provided in table 2 to determine the location of which will be selected as the location of the photo prewedding.

Table 2. Criteria Data

\begin{tabular}{cl}
\hline Code & \multicolumn{1}{c}{ Criteria } \\
\hline K1 & Location distance \\
K2 & Number of places \\
K3 & Transportation \\
K4 & Time \\
K5 & Location fee \\
K6 & Theme \\
\hline
\end{tabular}

The alternative is a main object in decisionmaking. The data used is the data location to determine the location of photo prewedding best in jakarta. Alternative data can be seen in table 3 .

Table 3. Alternative Data

\begin{tabular}{cl}
\hline Code & \multicolumn{1}{c}{ Alternative } \\
\hline A1 & Glodok \\
A2 & Kota tua \\
A3 & Taman wisata mangrove angke \\
& kapuk \\
A4 & Ancol \\
A5 & Cafe batavia \\
A6 & Pelabuhan sunda kelapa \\
\hline
\end{tabular}

\section{RESULTS AND DISCUSSION}

\section{Data Processing Using Analytical Hierarchy Process}

Here are the stages of completion of the calculation using the method of AHP.

\section{Creating a Hierarchical Structure}

Figure 3 is a Hierarchical Structure for the research conducted 


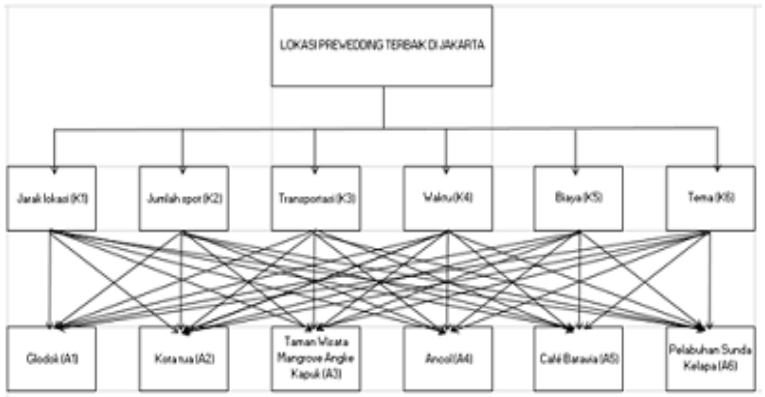

Figure 3. The structure of the hierarchy of the selection of the location prewedding best in Jakarta

\section{Assessment criteria and alternatives}

After the preparation of the hierarchy, can be done in the collection of value from the results of the questionnaire has been answered by 53 respondents. Because of having more than one respondent, then the next stage is to perform the calculation of the Geometric Mean (Pratiwi, MZ, \& Aprilyanti, 2018).

Weight ratings of some of the respondents in a group are averaged by using the assessment of the geometric (Geometric Mean). The goal is to get a single value that represent the number of respondents.

The formula used to find the geometric average is the following (Handayani \& Darmianti, 2017):

$\mathrm{G}=\sqrt[n]{X 1 * X 2 * \ldots X n}$

$\begin{array}{ll}\text { Description } & : \\ \mathrm{G} & : \text { Geometric mean } \\ \mathrm{Xn} & : \text { Assessment } 1,2,3 \ldots \mathrm{n} \\ \mathrm{n} & \text { : Number of ratings }\end{array}$

After getting the results of the geometric average of each respondent. Then, each value of the geometric average is inserted into the table of paired comparisons (pairwise comparison). Below shown table 4 shows the Pairwise Comparison Matrix Between Criteria, which is the results of searching for the average value of the ratio of the geometric numerous criteria.

Table 4. Pairwise Comparison Matrix Between

\begin{tabular}{ccccccc}
\multicolumn{7}{c}{ Criteria } \\
\hline Criteria & K1 & K2 & K3 & K4 & K5 & K6 \\
\hline K1 & 1,00 & 1,58 & 1,06 & 0,40 & 0,39 & 0,58 \\
K2 & 0,63 & 1,00 & 1,18 & 0,64 & 0,45 & 0,38 \\
K3 & 0,94 & 0,85 & 1,00 & 0,52 & 0,38 & 0,79 \\
K4 & 2,50 & 1,56 & 1,92 & 1,00 & 0,49 & 0,99 \\
K5 & 2,56 & 2,22 & 2,63 & 2,04 & 1,00 & 0,83 \\
K6 & 1,72 & 2,63 & 1,27 & 1,01 & 1,20 & 1,00 \\
\hline Amount & 9,36 & 9,84 & 9,06 & 5,61 & 3,91 & 4,57 \\
\hline
\end{tabular}

Table 5 shows the Pairwise Comparison Matrix Between Alternatives Based on the Criteria of Distance, which is the resultsof searching for the average value of the geometric comparison of alternatives based on the criteria of the distance of the location.

Table 5. Pairwise Comparison Matrix Between Alternatives Based on The Criteria Of Location Distance

\begin{tabular}{ccccccc}
\hline K1 & A1 & A2 & A3 & A4 & A5 & A6 \\
\hline A1 & 1,00 & 0,19 & 0,22 & 0,26 & 0,16 & 0,30 \\
A2 & 5,26 & 1,00 & 0,80 & 0,69 & 0,68 & 1,07 \\
A3 & 4,53 & 1,26 & 1,00 & 0,92 & 1,05 & 0,80 \\
A4 & 3,91 & 1,44 & 1,09 & 1,00 & 0,92 & 1,47 \\
A5 & 6,34 & 1,48 & 0,96 & 1,09 & 1,00 & 0,96 \\
A6 & 3,37 & 0,94 & 1,24 & 0,68 & 1,04 & 1,00 \\
\hline Amount & 24,40 & 6,31 & 5,30 & 4,64 & 4,84 & 5,60 \\
\hline
\end{tabular}

Pairwise Comparison Matrix Between Alternatives Based on the Criteria of the Number of spots can be seen in table 6 , which is the result of searching for the average value of the geometric comparison of alternatives based on the criteria of number of spot.

Table 6. Pairwise Comparison Matrix Between Alternatives Based on The Criteria of Number of

\begin{tabular}{ccccccc}
\multicolumn{7}{c}{ Spot } \\
\hline K2 & A1 & A2 & A3 & A4 & A5 & A6 \\
\hline A1 & 1,00 & 0,23 & 0,21 & 0,23 & 0,22 & 0,27 \\
A2 & 4,32 & 1,00 & 0,47 & 0,73 & 1,01 & 0,92 \\
A3 & 4,84 & 2,11 & 1,00 & 0,90 & 1,18 & 0,65 \\
A4 & 4,35 & 1,38 & 1,11 & 1,00 & 1,23 & 1,22 \\
A5 & 4,51 & 0,99 & 0,85 & 0,81 & 1,00 & 1,10 \\
A6 & 3,70 & 1,09 & 1,53 & 0,82 & 0,91 & 1,00 \\
\hline Amount & 22,72 & 6,80 & 5,17 & 4,49 & 5,55 & 5,17 \\
\hline
\end{tabular}

Pairwise Comparison Matrix Between Alternatives Based on the Criteria of Transport can be seen in table 7 , which is the results of searching for the average value of the geometric comparison of alternatives based on the criteria Transport.

Table 7. Pairwise Comparison Matrix Between Alternatives Based on The Criteria of Transport

\begin{tabular}{ccccccc}
\hline K3 & A1 & A2 & A3 & A4 & A5 & A6 \\
\hline A1 & 1,00 & 0,22 & 0,46 & 0,26 & 0,28 & 0,43 \\
A2 & 4,56 & 1,00 & 0,87 & 0,56 & 0,71 & 1,17 \\
A3 & 2,20 & 1,15 & 1,00 & 0,43 & 0,83 & 0,90 \\
A4 & 3,78 & 1,80 & 2,35 & 1,00 & 0,80 & 1,00 \\
A5 & 3,57 & 1,40 & 1,21 & 1,25 & 1,00 & 0,71 \\
A6 & 2,35 & 0,85 & 1,11 & 1,00 & 1,41 & 1,00 \\
\hline Amount & 17,45 & 6,42 & 6,99 & 4,50 & 5,03 & 5,21 \\
\hline
\end{tabular}

Table 8 shows the Pairwise Comparison Matrix Between Alternatives Based on the Criteria of Time, which is the result of searching for the 
average value of the geometric comparison of alternatives based on the criteria of Time.

Table 8. Pairwise Comparison Matrix Between

Alternatives Based on The Criteria of Time

\begin{tabular}{ccccccc}
\hline K4 & A1 & A2 & A3 & A4 & A5 & A6 \\
\hline A1 & 1,00 & 0,19 & 0,30 & 0,25 & 0,38 & 0,55 \\
A2 & 5,24 & 1,00 & 0,59 & 0,60 & 0,84 & 1,03 \\
A3 & 3,30 & 1,69 & 1,00 & 0,67 & 0,90 & 0,77 \\
A4 & 4,03 & 1,66 & 1,49 & 1,00 & 0,84 & 1,15 \\
A5 & 2,62 & 1,20 & 1,11 & 1,20 & 1,00 & 0,84 \\
A6 & 1,82 & 0,97 & 1,30 & 0,87 & 1,19 & 1,00 \\
\hline Amount & 18,01 & 6,71 & 5,79 & 4,58 & 5,14 & 5,35 \\
\hline
\end{tabular}

Table 9 is the Pairwise Comparison Matrix Between Alternatives Based on the Criteria of the Cost of the Location, which is the result of searching for the average value of the geometric comparison of alternatives based on the criteria of Cost Locations.

Table 9. Pairwise Comparison Matrix Between Alternatives Based On The Criteria Of Cost Locations

\begin{tabular}{ccccccc}
\hline K5 & A1 & A2 & A3 & A4 & A5 & A6 \\
\hline A1 & 1,00 & 0,31 & 0,62 & 0,33 & 0,45 & 0,66 \\
A2 & 3,21 & 1,00 & 0,78 & 0,54 & 1,11 & 1,01 \\
A3 & 1,62 & 1,28 & 1,00 & 0,53 & 0,69 & 0,70 \\
A4 & 3,03 & 1,86 & 1,89 & 1,00 & 0,73 & 0,96 \\
A5 & 2,20 & 0,90 & 1,46 & 1,38 & 1,00 & 0,85 \\
A6 & 1,52 & 0,99 & 1,43 & 1,04 & 1,18 & 1,00 \\
\hline Amount & 12,58 & 6,34 & 7,17 & 4,81 & 5,16 & 5,18 \\
\hline
\end{tabular}

Table 10 is a Pairwise Comparison Matrix Between Alternatives Based on the Criteria of the Theme, which is the result of searching for the average value of the geometric comparison of alternatives based on the criteria of the Theme.

Table 10. Pairwise Comparison Matrix Between Alternatives Based On The Criteria Of The Theme

\begin{tabular}{ccccccc}
\hline K6 & A1 & A2 & A3 & A4 & A5 & A6 \\
\hline A1 & 1,00 & 0,21 & 0,23 & 0,18 & 0,24 & 0,31 \\
A2 & 4,88 & 1,00 & 0,45 & 0,37 & 0,77 & 0,84 \\
A3 & 4,40 & 2,23 & 1,00 & 0,63 & 0,87 & 0,90 \\
A4 & 5,71 & 2,70 & 1,58 & 1,00 & 0,70 & 1,02 \\
A5 & 4,20 & 1,30 & 1,15 & 1,42 & 1,00 & 0,67 \\
A6 & 3,27 & 1,19 & 1,12 & 0,98 & 1,49 & 1,00 \\
\hline Amount & 23,45 & 8,62 & 5,52 & 4,58 & 5,07 & 4,73 \\
\hline
\end{tabular}

Perbandingan Comparison of criteria and alternatives is filled with a single value that represents the number of respondents in accordance with what has been established when searching for a geometric average. Then, prepared in accordance with the scale of assessment of pairwise comparison. The last process that is the sum of the value of a column on each table paired comparison.

\section{Specify the Priority (Synthesis of priority) and Measuring Consistency}

Thingking of the pairwise comparison synthesized to get all of the priorities. How that is done in this phase is to add up the values of each column in the matrix, divide each value of the column with the total of the column in question to obtain the normalization of the matrix, summing the values of each row and divide it by the number of elements to get the average value (Handayani \& Darmianti, 2017). Whereas, to measure consistency in decision-making, it is important to be aware of how well the consistency of the obtained because the researcher would not expect to get a decision based on considerations with low consistency (Azhar, 2019).

\section{The Determination of The Weights Between Criteria}

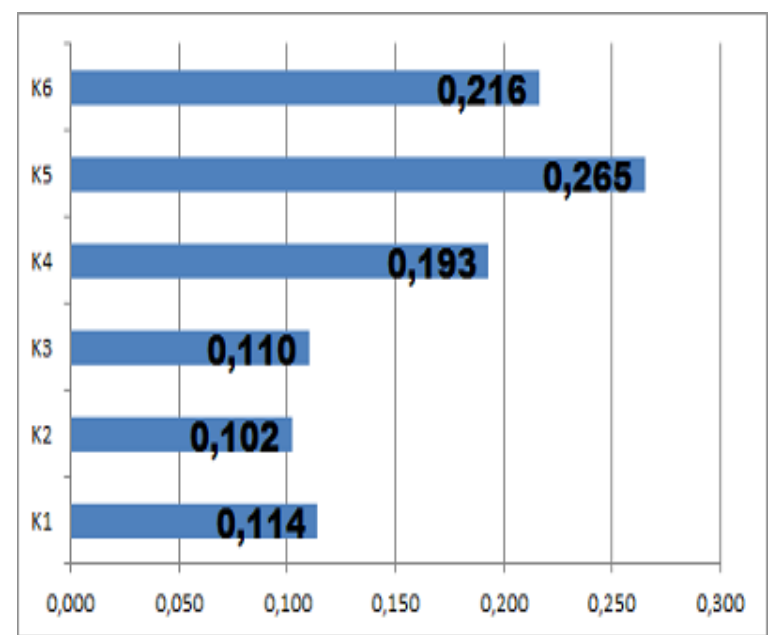

Figure 4 . The normalization of the matrix between criteria

Figure 4 shows the Normalization of the matrix between criteria, is the result obtained after performing the calculation in finding the average or the priority value in the normalization between the criteria. Based on the results obtained, the highest priority is the cost of the location (K5) with the value of the weight $0,265(27 \%)$ of the total criteria, the priority of rank 2 is a theme (K6) with the value of the weight $0,216(22 \%)$, the priority rank 3 is the time (K4) with the value of the weight 0,193 (19\%), priority in rank to 4 are the distance (K1) with the value of the weight $0,114(11 \%)$, priority in rank to 5 is transportation (K3) with the value of the weight $0,110(11 \%)$, and priority in the ranking of the last is the number of spot (K2) with the value of the weight 0,102 (10\%).

After obtaining the weights of criteria (vector priority). The will check the consistency of 
the data to calculate the Consistency ratio (CR), it takes the $\lambda$ max and the Consistency Index (CI). Find the value of $\lambda$ max, the results obtained $\lambda$ max $=$ 6,17 . Find the value of Consistency Index (CI), is produced by 0,035 . Calculate the Consistency Ratio (CR), the results obtained 0,028 (the results obtained is less than 0,1 then it could be said to be consistent).

The Determination of The Weights Between Alternatives Based On The Criteria of Distance (K1)

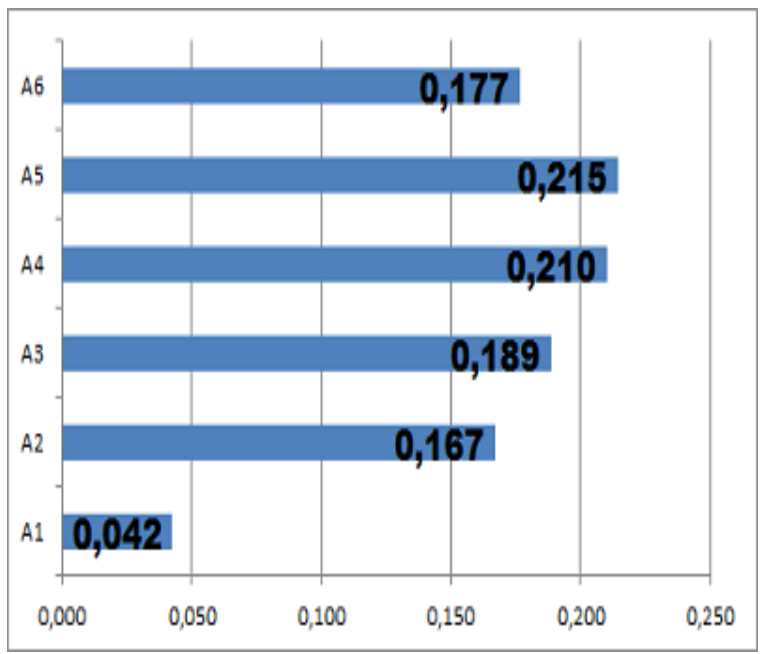

Figure 5. The normalization of the matrix between alternatives based on the criteria of location distance

The normalization of the matrix between alternatives based on the criteria of the distance of the location can be seen in figure 5 , is the result obtained after performing the calculation in finding the average or the priority value in the normalization between alternatives based on the criteria of the distance of the location. Based on the results obtained, the highest priority is the cafe batavia (A5) with the value of the weight 0,215 $(21 \%)$ of the total alternative, the priority rank 2 is ancol (A4) with the value of the weight 0,210 (21\%), priority in rank 3 is to tourist park mangrove angke kapuk (A3) with the value of the weight 0,189 (19\%), the priority at rank 4 is the port of sunda kelapa (A6) with the value of the weight 0,177 $(18 \%)$, priority in rank to 5 is the old town (A2) with the value of the weight $0,167(17 \%)$, and priority in the ranking latter is glodok (A1) with the value of the weight $0,042(4 \%)$.

After obtaining the weights of criteria (vector priority). Then will check the consistency of the data to calculate the Consistency ratio (CR), it takes the $\lambda$ max and the Consistency Index (CI). Find the value of $\lambda$ max, the results obtained $\lambda \max =6,09$.
Find the value of Consistency Index (CI), resulting 0,018. Calculate the Consistency Ratio (CR), the results obtained 0,015 (the result obtained is less than 0.1 then it could be said to be consistent).

\section{The Determination of The Weights Between Alternatives Based On The Criteria of Number Of Spot (K2)}

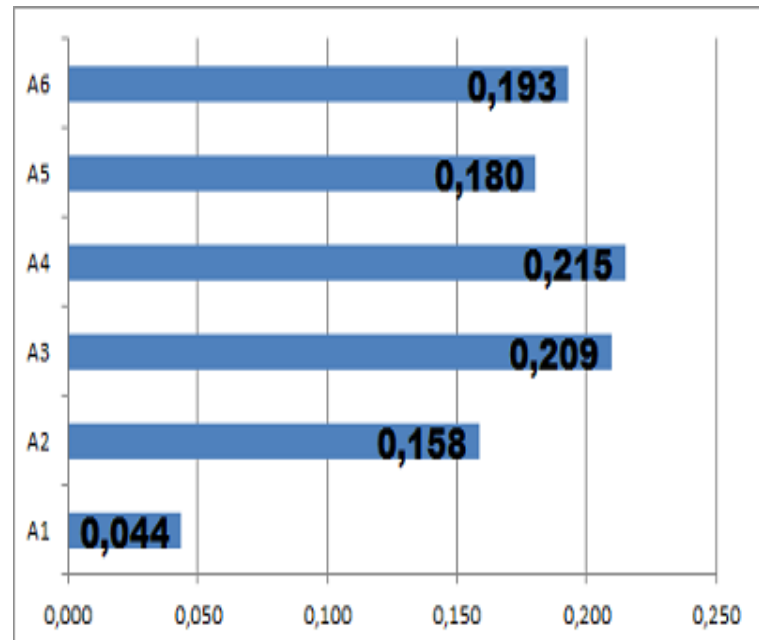

Figure 6. The normalization of the matrix between alternatives based on the criteria of number of spot

Figure 6. is the normalization of the matrix between alternatives based on the criteria of number of spot, is the result obtained after performing the calculation in finding the average or the priority value in the normalization between alternatives based on the criteria of number of spot. Based on the results obtained, the highest priority is ancol (A4) with the value of the weight 0,215 (22\%) of the total alternative, the priority rank 2 is tourist park mangrove angke kapuk (A3) with the value of the weight $0,209(21 \%)$, priority in rank to 3 is the port of sunda kelapa (A6) with the value of the weight $0,193(19 \%)$, priority in rank to 4 is a cafe batavia (A5) with a weight value of 0.180 (18\%), priority in rank to 5 is the old town (A2) with the value of the weight to $0.158(16 \%)$, and priority in the ranking latter is glodok (A1) with the value of the weight 0,044 (4\%).

After obtaining the weights of criteria (vector priority). Then will check the consistency of the data to calculate the Consistency ratio (CR), it takes the $\lambda$ max and the Consistency Index (CI). Find the value of $\lambda \max$, the results obtained $\lambda \max =6,11$. Find the value of Consistency Index (CI), is produced by 0,023 . Calculate the Consistency Ratio (CR), the results obtained 0,018 (the result obtained is less than 0.1 then it could be said to be consistent). 
The Determination of The Weights Between Alternatives Based on The Criteria of Transportation (K3)

Figure 7 is a normalization matrix between alternatives based on the criteria of transportation, is the result obtained after performing the calculation in finding the average or the priority value in the normalization between alternatives based on the criteria of transport. Based on the results obtained, the highest priority is ancol (A4) with the value of the weight $0,234(23 \%)$ of the total alternative, the priority of rank 2 is a cafe batavia (A5) with the value of the weight 0,201 (20\%), the priority rank 3 is the port of sunda kelapa (A6) with the value of the weight $0,187(19 \%)$, the priority at rank 4 is the old town (A2) with the value of the weight $0,172(17 \%)$, priority in rank to 5 is tourist park mangrove angke kapuk (A3) with a weight value of $0.147(15 \%)$, and priority in the ranking latter is Glodok (A1) with the value of the weight 0,059 (6\%).

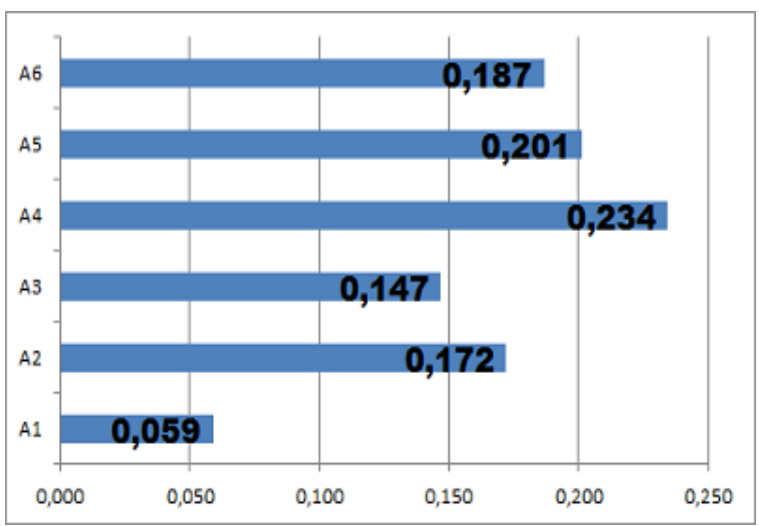

Figure 7. The normalization of the matrix between alternatives based on the criteria of transport

After obtaining the weights of criteria (vector priority). Then will check the consistency of the data to calculate the Consistency ratio (CR), it takes the $\lambda$ max and the Consistency Index (CI). Find the value of $\lambda$ max, the results obtained $\lambda \max =6,20$. Find the value of Consistency Index (CI), is produced by 0.039 to. Calculate the Consistency Ratio (CR), the results obtained to 0.032 (the result obtained is less than 0.1 then it could be said to be consistent).

\section{The Determination of The Weights Between} Alternatives Based On The Criteria Of Time (K4)

The normalization of the matrix between alternatives based on the criteria of time can be seen in figure 8 , is the result obtained after performing the calculation in finding the average or the priority value in the normalization between alternatives based on the criteria of time. Based on the results obtained, the highest priority is ancol (A4) with the value of the weight $0,221(22 \%)$ of the total alternative, the priority of rank 2 is a cafe batavia (A5) with the value of the weight 0,188 (19\%), the priority rank 3 is the port of sunda kelapa (A6) with the value of the weight 0,1794 (18\%), priority in rank to 4 is tourist park mangrove angke kapuk (A3) with the value of the weight 0,1789 (18\%), priority in rank to 5 is the old town (A2) with the value of the weight $0,171(17 \%)$, and priority in the ranking latter is Glodok (A1) with the value of the weight $0,061(6 \%)$.

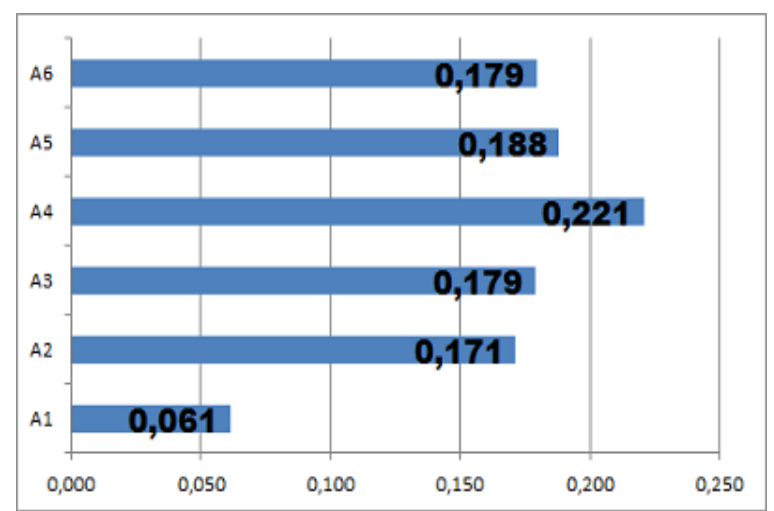

Figure 8. The normalization of the matrix between alternatives based on the criteria of time

After obtaining the weights of criteria (vector priority). Then will check the consistency of the data to calculate the Consistency ratio (CR), it takes the $\lambda$ max and the Consistency Index (CI). Find the value of $\lambda$ max, the results obtained $\lambda$ max $=6,23$. Find the value of Consistency Index (CI), is produced by 0,046 . Calculate the Consistency Ratio (CR), the results obtained 0,037 (the result obtained is less than 0.1 then it could be said to be consistent).

The Determination of The Weights Between Alternatives Based On The Criteria of Cost Locations (K5)

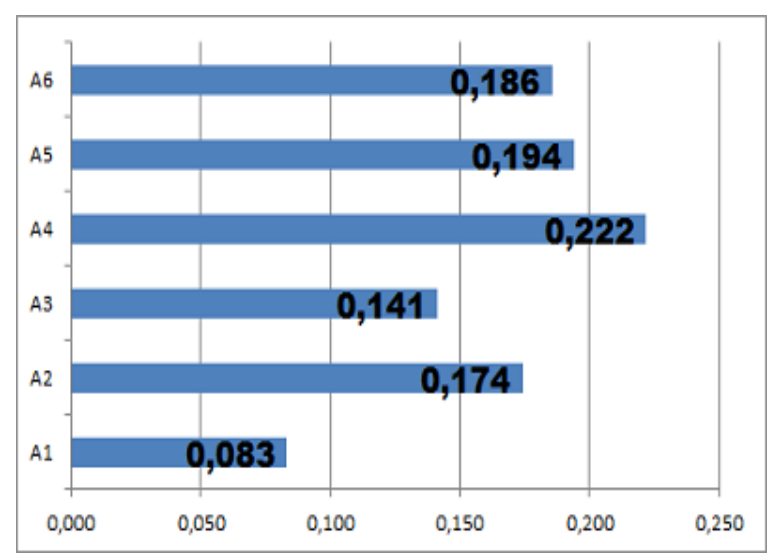

Figure 9. The normalization of the matrix between alternatives based on the criteria of cost locations 
Figure 9 shows the normalization of the matrix between alternatives based on the criteria of cost locations, is the result obtained after performing the calculation in finding the average or the priority value in the normalization between alternatives based on the criteria of cost locations. Based on the results obtained, the highest priority is ancol (A4) with the value of the weight 0,222 (22\%) of the total alternative, the priority of rank 2 is a cafe batavia (A5) with the value of the weight 0,194 (19\%), the priority rank 3 is the port of sunda kelapa (A6) with the value of the weight 0,186 (19\%), the priority at rank 4 is the old town (A2) with the value of the weight 0,174 (17\%), priority in rank to 5 is tourist park mangrove angke kapuk (A3) with the value of the weight content 0,141 (14\%), and priority in the ranking latter is Glodok (A1) with the value of the weight $0,083(8 \%)$.

After obtaining the weights of criteria (vector priority). Then will check the consistency of the data to calculate the Consistency ratio (CR), it takes the $\lambda$ max and the Consistency Index (CI). Find the value of $\lambda$ max, the results obtained $\lambda \max =6,23$. Find the value of Consistency Index (CI), is produced by 0,046. Calculate the Consistency Ratio (CR), the results obtained 0,037 (the result obtained is less than 0.1 then it could be said to be consistent).

The Determination of The Weights Between Alternatives Based On The Criteria of The Theme (K6)

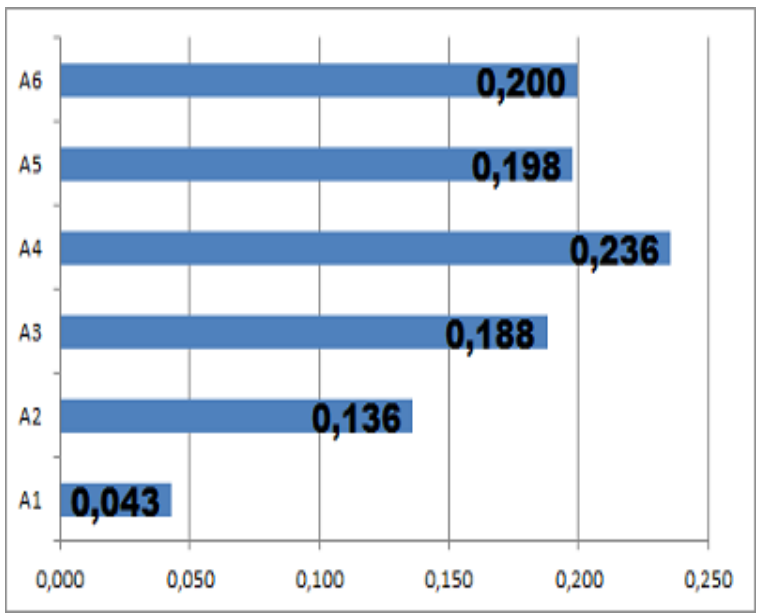

Figure 10. Normalisai matrix between alternatives based on the criteria of the theme

Figure 10 shows the normalization of the matrix between alternatives based on the criteria of the theme, is the result obtained after performing the calculation in finding the average or the priority value in the normalization between alternatives based on the criteria of the theme. Based on the results obtained, the highest priority is ancol (A4) with the value of the weight $0,236(24 \%)$ of the total alternative, the priority rank 2 is the port of sunda kelapa (A6) with the value of the weight 0,200 (20\%), the priority rank 3 is a cafe batavia (A5) with the value of the weight 0,198 (20\%), priority in rank to 4 is tourist park mangrove angke kapuk (A3) with the value of the weight $0,188(19 \%)$, the priority at rank 5 is the old town (A2) with the value of the weight $0,136(14 \%)$, and priority in the ranking latter is Glodok (A1) with the value of the weight $0,043(4 \%)$.

After obtaining the weights of criteria (vector priority). Then will check the consistency of the data to calculate the Consistency ratio (CR), it takes the $\lambda$ max and the Consistency Index (CI). Find the value of $\lambda \max$, the results obtained $\lambda \max =6,24$. Find the value of Consistency Index (CI), is produced by 0,049 . Calculate the Consistency Ratio (CR), the results obtained 0.039 to (the result obtained is less than 0.1 then it could be said to be consistent).

\section{Ranking}

After doing some calculations, and then create a table ranking. Ranking was conducted to determine the location of the photo prewedding best in Jakarta. Table 11 shows the results of ranking. The appearance of the ranking in the form of diagrams can be seen in figure 11 which is the result of the calculation of the value in preferences on each alternative.

Table 11. Table Of Results Ranking

\begin{tabular}{clcc}
\hline Kode & \multicolumn{1}{c}{ Lokasi } & Preferensi & Peringkat \\
\hline A1 & Glodok & 0,058840858 & 6 \\
A2 & The old town & 0,162696386 & 5 \\
& Tourist Park & 0,171584976 & 4 \\
A3 & $\begin{array}{l}\text { Mangrove } \\
\text { Angke kapuk }\end{array}$ & & \\
A4 & Ancol & $\mathbf{0 , 2 2 4 0 4 7 7 2 1}$ & $\mathbf{1}$ \\
A5 & Café Batavia & 0,195494507 & 2 \\
A6 & The port of & 0,187335550 & 3 \\
\hline
\end{tabular}

On the determination of the ranking of the site consists of the multiplication between the priority or the average in the table normalization between the criteria with a priority of each alternative based on 6 criteria used. After that, the result of the multiplication directly summed. The results show that the Ancol with the value of the preference 0,224047721 be the place of location of photo prewedding best in jakarta. 


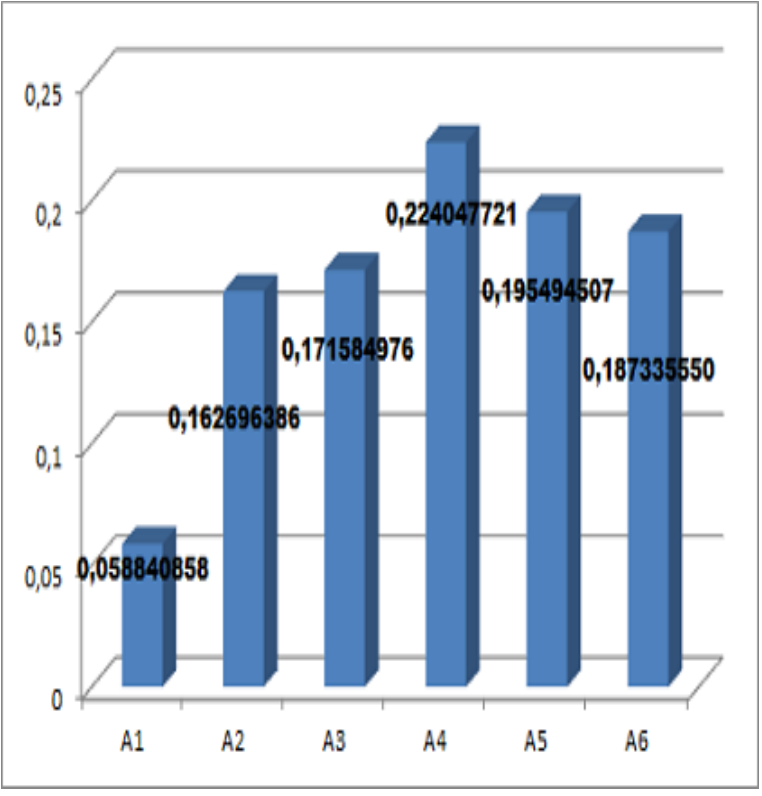

Figure 11. The appearance of the ranking in the form of a diagram

\section{CONCLUSIONS AND SUGGESTIONS}

\section{Conclusions}

In the results of calculations using the method of Analytical Hierarchy Process, earned the priority of the most important criteria in determining the best location in the photo prewedding in Jakarta, where the distance of the location, number of spots, transportation, time, cost, location, and theme to be a priority in determining the location of photo prewedding best in Jakarta. The results of the analysis stated that the alternative Ancol with the value of the preference 0,224047721 be the location of photo prewedding best in Jakarta. Excess use of AHP according to the experience of researchers in its use, particularly when you have the problem of multi respondents or problems that have a lot of opinions. By forming the structure of the hierarchy, the problem of it being visible can be overcome in such a way.

\section{Suggestions}

Expected to continue the research with the theme of the tools using the method of decision support system to another, such as the use of the method of Topsis, Moora, etc. Moreover, it can add a criteria other than the criteria used in this study.

\section{REFERENCES}

Azhar, Z. (2019). Analisis Pemilihan Mata Kuliah Praktek Menggunakan Metode AHP. Prosiding Seminar Nasional Riset Information Science
(SENARIS), $\quad 1$ (September), 1131. https://doi.org/10.30645/senaris.v1i0.126

Frieyadie. (2018). Metode AHP Sebagai Penunjang Keputusan Untuk Penilaian Kinerja Kerja Karyawan SPBU. Jurnal TECHNO Nusa Mandiri, 15(1), 63-68.

Handayani, R. irma, \& Darmianti, Y. (2017). Pemilihan Supplier Bahan Baku Bangunan Dengan Metode Analytical Hierarchy Process (AHP) Pada PT. Cipta Nuansa Prima Tangerang. Jurnal Techno Nusa Mandiri, $14(1)$,

$1-8$. https://doi.org/10.33480/techno.v14i1.176

Kusuma, Y. (2010). Trik Foto Pre-wedding Kreatif. Grasindo.

Latif, L. A., Jamil, M., \& Abbas, S. H. (2018). Buku Ajar: Sistem Pendukung Keputusan Teori dan Implementasi (1st ed.). Yogyakarta: Deepublish.

Muhaimin Hasanudin, Yansen Marli, B. H. (2018). Sistem Pendukung Keputusan Pemilihan Karyawan Terbaik Menggunakan Metode Analytical Hierarchy Process ( Studi Kasus Pada Pt . Bando Indonesia ). Seminar Nasional Teknologi Informasi Dan Multimedia 2018, 6(3), 91-96.

Nurhidayah, S., Fauzan, M. N., \& Rahayu, W. I. (2020). Implementasi Metode Analytic Hierarchy Process (AHP) dengan PHP. Kreatif Industri Nusantara.

Pratiwi, I., MZ, H., \& Aprilyanti, S. (2018). Pemilihan Supplier Terbaik Penyedia Barang Consumable Menggunakan Metode Analytical Hierarchy Process (Studi kasus di Departemen Pengadaan Barang PT. PUSRI). Jurnal Manajemen Industri Dan Logistik, 2(2), 147158. https://doi.org/10.30988/jmil.v2i2.35

Safitri, K., \& Tinus Waruwu, F. (2017). Sistem Pendukung Keputusan Pemilihan Karyawan Berprestasi Dengan Menggunakan Metode Analytical Hieararchy Process (Studi Kasus : PT.Capella Dinamik Nusantara Takengon). 1(1), 12-16.

Sanyoto, G. P., Handayani, R. I., \& Widanengsih, E. (2017). Sistem Pendukung Keputusan Pemilihan Laptop Untuk Kebutuhan Operasional Dengan Metode AHP (Studi Kasus: Direktorat Pembinaan Kursus Dan Pelatihan Kemdikbud). Jurnal Pilar Nusa Mandiri, 13(2), 167-174.

Syahputra, M. R., Winanjaya, R., \& Okprana, H. (2019). Sistem Pendukung Keputusan Pemilihan Lokasi Prewedding Menggunakan Metode Weight Product. KOMIK (Konferensi Nasional Teknologi Informasi Dan Komputer), $3(1)$, 695-701. https://doi.org/10.30865/komik.v3i1.1680 
Utama, D. N. (2017). Sistem Penunjang Keputusan:

Filosofi Teori dan Implementasi. In Garudhawaca. Yogyakarta: Garudhawaca. 